\title{
US under pressure from Europe to share data
}

\section{Washington}

Now that negotiations on allied participation in the Strategic Defense Initiative (SDI) have begun in earnest, the US government and the Pentagon are coming under strong pressure from the British and West German governments to grant full access to technical know-how gathered in the course of the development as part of the price of overseas participation. But the British government has also raised the possibility that participation might not be worthwhile unless the value of the contracts awarded to British companies and research organizations reaches some predetermined value - $\$ 1,500$ million has been mentioned, to the consternation of some administration officials.

The report that the British government is asking for contracts worth at least $\$ 1,500$ million appeared last week in the Baltimore News newspaper and has been obliquely confirmed. But British officials have said that any figure mentioned at this early stage should be regarded as an "opening bid", rather more an indication of the scale on which the Pentagon should be thinking than as an ultimatum.

Negotiations appear to be at a relatively early stage, with the arrangements for dealing with the security of classified information during the research phase of SDI agreed but not yet formally adopted. One of the points made by British negotiators is that any involvement of British companies as contractors for SDI will involve the British government in supervision and monitoring on a substantial scale, the cost of which would be far from negligible. But the chief concern is that companies or other research entities involved with SDI should not be dealt with as mere research contractors and recompensed on the basis of the time and trouble expended, but that they should be genuine partners in the parts of SDI in which they are engaged.

SDI is likely to centre on fields such as infrared sensors (the basis of boost-phase detection) and signal-processing, in both of which British defence research establishments and associated defence manufacturers have some expertise. One of the British demands is that there should be no restraint and British companies should not be at a disadvantage, compared with US participants, in the later exploitation of developments in which they have been engaged.

A more distant and more difficult issue, raised chiefly by the government of West Germany, is whether governments and national companies participating in SDI should also have access to the later com- mercial exploitation of technical innovations in which they have not been directly involved.

Even though these questions have not yet been decided, the United States appears to be in some haste to bring the negotiations to a conclusion. With the sequence of diplomatic meetings planned for next month and thereafter, the bilateral summit in November chief among them, there are obvious benefits in being able to announce allied participation in SDI. No doubt the potential partners have made similar calculations. Just what price will be struck for the political advantage and the technical assistance may be the kind of question the game of poker is designed to answer.

UK overseas students

\section{Market forces shrink demand}

FIVE years after the British government's decision to require overseas students to pay a full "economic" rate for their college or university education, the numbers are still in decline. A report from the Commonwealth Secretariat estimates that the number of overseas students has dropped to some 55,600, a fall of more than 30,000 since the introduction of full-cost fees in 1980 , including a fall of 1,000 last year.

Despite a declaration from Common wealth education ministers meeting in Nicosia (Cyprus) last year that it is important to foster the exchange of students between member nations, the Commonwealth Secretariat notes that exchanges within the Commonwealth are on the decline, but that elsewhere student mobility is increasing. West Germany now accepts 72,000 foreign students and appears to be taking more students from Commonwealth countries no longer able to send as many to the United Kingdom including Cyprus, Tanzania and Kenya.

The United States remains by far the largest host nation, with some 340,000 foreign students. France has more than twice as many as the United Kingdom $(128,000)$ and the Soviet Union has 82,500 . Japan, at present with some 10,000 foreign students, plans to expand this to 100,000 by the end of the century.

The foreign policy implications of providing places for overseas students were recognized by the British government in 1983 when, after considerable pressure from the Commonwealth (most vocifer ously from Malaysia), the then Foreign Secretary Mr Francis Pym announced a three-year $£ 46$ million package to sub sidize overseas students. The "Pym package", now entering its last year, singles out certain countries as specially deserving cases-Cyprus, for instance, with a large refugee population, no major university

\begin{tabular}{lccccc}
\multicolumn{6}{c}{ Foreign students in higher education in Britain, $\mathbf{1 9 7 9 - 8 0}$ to $\mathbf{1 9 8 3 - 8 4}$} \\
Commonwealth & $1979-80$ & $1980-81$ & $1981-82$ & $\mathbf{1 9 8 2 - 8 3}$ & $1983-84$ \\
Non-Commonwealth & 43,630 & 38,718 & 32,710 & 28,016 & 27,370 \\
Total & 44,407 & 38,912 & 31,361 & 28,649 & 28,238 \\
$\begin{array}{l}\text { (Commonwealth as } \\
\quad \% \text { of total) }\end{array}$ & 88,037 & 77,630 & 64,071 & 56,665 & 55,608 \\
& $(49.5 \%)$ & $(50 \%)$ & $(51 \%)$ & $(49 \%)$ & $(49 \%)$
\end{tabular}

Source: British Council and strategic importance to Britain - as well as potentially influential individuals from potential trading partners.

The clear determination that the United Kingdom should get "value for money" for overseas students supported financi ally underlines the economic problem of fostering an exchange between the developed and developing nations. With a brief that the mobility of students between Commonwealth countries is a good thing no matter in which direction the move ments take place, the committee responsible for the report suggests that the less developed countries with relatively sophisticated university systems might be encouraged to take increasing numbers of students from countries with few universities.

Not only the supply of university places is affected by economic pressures. Shortage of foreign currency means that the demand is also depressed in countries such as Nigeria and Malaysia, even if the cost of education in host nations is not increasing.

In the immediate future, the current trend in Britain seems likely to continue, as fees are due to increase by a further 5 per cent for the year 1985-86. But for the long term, the committee raises the possibility that student exchanges may not be indispensable for sharing the access to high-level institutions. New information technologies, says the Commonwealth Secretariat, should be considered as an alternative. If the best learning in the world is available at the nearest computer terminal and telephone line, will there be any need for the students to stir from home?

Charles Wenz

"Commonwealth Student Mobility: A Way Forward", is the fourth report of the Commonwealth Standing Committee on Student Mobility Commonwealth Secretariat, Marlborough House, London SW1 SHX,UK). 